\title{
Hepatotoxicity associated with statins
}

\author{
Bensu Karahalil, Emine Hare, Göksel Koç, İrem Uslu, Kerem Şentürk, and Yağmur Özkan \\ Toxicology Department, Faculty of Pharmacy, Gazi University Ankara, Turkey
}

[Received in May 2017; Similarity Check in May 2017; Accepted in October 2017]

\begin{abstract}
Treatment with statins is known all over the world. They are generally considered safe at therapeutic doses. Nevertheless, clinical trials are not enough to assess their scarce adverse effects such as idiosyncratic drug induced liver injury (DILI). Due to some conditions, such as concomitant usage (drug-drug interaction using an identical metabolising enzyme) and genetic polymorphisms, there is an increasing concern about their safety. Hepatotoxicity and rhabdomyolysis have begun to appear in published studies. Most of investigations have focused on both these adverse effects and mechanisms of drug induced toxicity. The present review has attempted to compile almost all of the existing studies on the hepatotoxicity of statins but not rhabdomyolysis. The aim of our study is to provide an overview of the studies on the statin-associated hepatotoxicity and to discuss the published studies. The researchers are of the opinion that the research on this topic is incomplete but extremely necessary.
\end{abstract}

KEY WORDS: DILI; drugs; meta-analysis; epidemiological studies

Drug-induced liver injury (DILI) is a major complication with many drugs. Drug induced acute hepatic injury occurs in 5 to $10 \%$ of patients hospitalised for jaundice (1-4). Furthermore, drugs are the most common cause of fulminant hepatic failure, both in the United States and Europe $(5,6)$. In the reports from the United States and Sweden, idiosyncratic drug reactions (IDRs) were the hypothetical reasons in $13 \%$ of the cases of acute liver failure (ALF) in the USA and $1 \%$ in Sweden $(5,7)$. The prognosis for patients with ALF due to IDRs is usually poor. Without liver transplantation, mortality rates can be as high as 60 $80 \%(8,9)$. During the last decade, DILI has led to withdrawal of a number of drugs from the market (10-14). Reports on the frequency of adverse reactions involving statins indicate $4.2 \%$ of cases in New Zealand, $1.4 \%$ in France, $5.9 \%$ in Denmark, $1.4 \%$ in India, and about $10 \%$ in the United States (15-17). Hepatocellular injury and jaundice resulting from the administration of different drugs (such as isoniazid $10 \%$ and halothane $50 \%$ ) lead to a mortality rate of 10 to $50 \%(11-13)$. This phenomenon is known as "Hy's rule". According to the rule, both druginduced hepatocellular (HC) injury and jaundice occur at the same time without biliary obstruction and $10 \%$ mortality can be anticipated $(11,13,14)$. Hy's rule is defined as DILI with serum alanine aminotransferase (ALT) levels 3 or more times the upper limit of normal (ULN) and serum bilirubin levels 2 or more times the ULN. It has been used to assess the hepatotoxicity of newly developed drugs and is encouraged by the U.S. Food and Drug Administration (FDA) (13). According to this rule, in Sweden, 712 of 784

Correspondence to: Prof Dr Bensu Karahalil, Toxicology Department, Faculty of Pharmacy, Gazi University, 06330, Ankara, Turkey,

E-mail: bensuka@gmail.com
(90.8 \%) DILI patients with jaundice recovered, and 72 $(9.2 \%)$ died or underwent liver transplant surgery. Women are generally considered more at risk of DILI (18).

\section{The classification of drug induced hepatotoxicity}

DILI covers a variety of types and contains most of the clinical and pathological expressions of liver damage. Figure 1 shows drug-induced hepatotoxicity types (19). Statins are generally used for hyperlipidaemia. They competitively inhibit 3-hydroxy-3-methylglutarylcoenzyme A (HMG-CoA) reductase that is necessary for cholesterol biosynthesis. Statins play important roles via several ways in decreasing the level of low density lipoproteins (LDLs) and increasing the stability of atherosclerotic plaques. Therefore, they are effective in reducing cardiovascular mortality. According to the PubMed database, researchers are widely focused on six statins. These statins are presented in Figure 2 (19-23).

In the USA, in a DILI study, the longest-term study carried out on statins, statins were prescribed for patients with hyperlipidaemia. It was found that these were generally well tolerated. Small elevations in serum ALT and aspartate aminotransferase (AST) were observed (up to $3 \%$ of treated patients), but clinically DILI was rare. Of 1,188 cases of DILI enrolled between 2004 and 2012 in a prospective registry by the U.S. DILI Network, 22 cases were attributed to statins. The latency period to the onset of liver injury ranged from 34 days to 10 years. Median peak levels were $892 \mathrm{U} \mathrm{L}^{-1}$ for serum ALT, $358 \mathrm{U} \mathrm{L}^{-1}$ for alkaline phosphatase (AP), and $6.1 \mathrm{mg} \mathrm{dL}^{-1}$ for total bilirubin. Nine patients had cholestatic hepatitis and 12 patients had hepatocellular injury, of which six had an autoimmune phenotype. Nine 


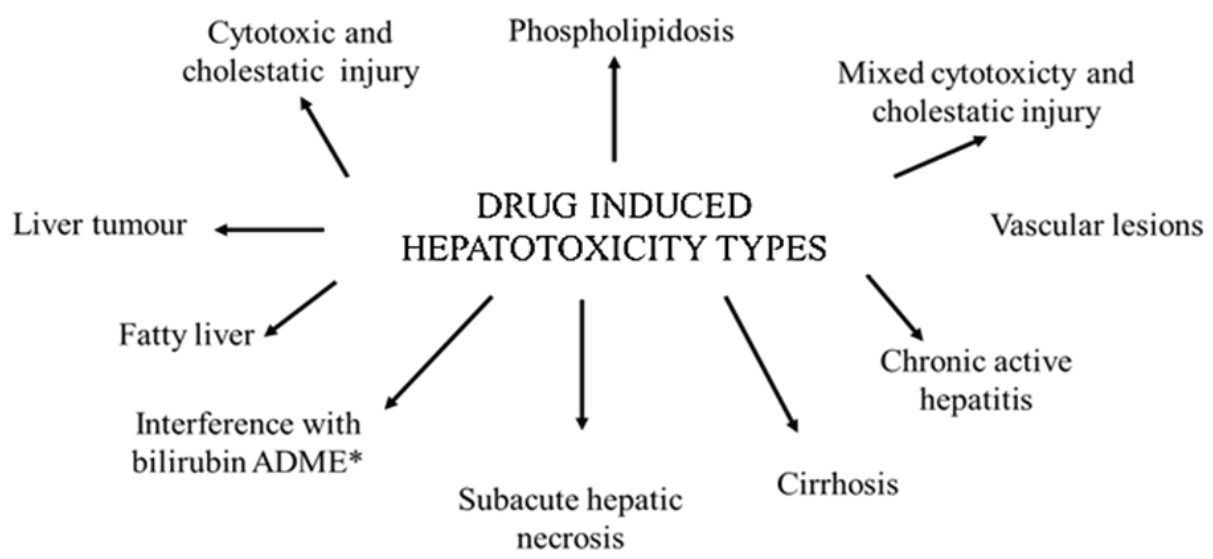

Figure 1 Drug-induced hepatotoxicity types; *ADME-Absorption, distribution, metabolism, and excretion

patients were hospitalised, four patients developed hepatic failure, and one died (24).

\section{Hepatic toxicity/injury mechanism/s of statins}

So far, different hepatotoxicity mechanisms have been proposed, some of which have been completely explained. However, most hepatotoxicity mechanisms have not been entirely understood and therefore researchers keep conducting studies. The present review focused on statin induced hepatotoxicity and possible hepatotoxicity mechanisms. Many observational studies in North America and Europe have confirmed that there are inconsistent results on the unintended effects of statins. Statins are related to lower risks of dementia and cognitive impairment, venous thromboembolism, fractures and pneumonia while they have not been related to any increased risk of depression, arthritis, renal disorders, or common eye diseases. However, it is well known that statins increase liver enzymes, risk of myopathy, and risk of diabetes mellitus (DM) (25). The most common complications related to statins are hepatotoxicity and myopathy. Hepatotoxicity and myopathy occur with the use of statins and the incidence of these effects increases when these are used;

i. at maximum doses

ii. together with other lipid lowering drugs such as fibrates (drug-drug interaction)

iii. with drugs which use the same enzymatic pathway such as some cytochrome P450 enzymes

iv. by elderly subjects and subjects having considerable hepatic and/or renal dysfunction (26).

Animal experiments revealed that liver toxicity not observed at therapeutic doses was seen at higher doses of statins. High doses of lovastatin in rabbits and simvastatin in guinea pigs caused necrosis in hepatic cells (21). The liver injury in these animals can be prevented or reversed by mevalonate reinforcement since the consumption of mevalonate or its downstream metabolites may be responsible for the injury (27).
The main biomarkers of liver abnormalities are aminotransferases. Different liver abnormalities are listed below according to the levels of aminotransferases;

i. Asymptomatic elevations of ALT) (generally moderate and temporary; ALT $<3 \times \mathrm{ULN}$ ),

ii. Hepatitis: with ALT $>3 \times$ ULN and clinical symptoms of liver injury,

iii. Cholestatic or mixed hepatitis: with improvement of icterus

iv. Autoantibody associated DILI with presence of antinuclear antibody (ANA) and antismooth muscle antibody (AMA) or antimitochondrial antibody (AMiA) with or without plasma cells upon liver biopsy. ALF does not improve in majority of subjects who use statins (28).

The exact mechanism by which statins cause liver injury is not well understood (29). Mitochondrial dysfunction is one of the major factors that explain the mechanism of statin-induced hepatotoxicity. The dose- and timedependent impairment of mitochondrial function by statins was shown in in vitro models. After statin treatment, there has been a significant increase in mitochondrial superoxide, which is determined by the mitochondrial toxicity assay. This increase leads to significant mitochondrial impairment. Another major reason for statin induced hepatotoxicity is that statins cause apoptotic cell death. In particular, cerivastatin was withdrawn from the market in 2001 due to DILI (30). Other possible hepatotoxicity mechanisms are the inhibition of the respiratory chain (complex I and III), depolarisation of mitochondrial membrane, and release of $\mathrm{Ca}^{+2}$

Drugs are metabolised by the liver cytochrome P450 enzymes. These enzymes include a super -family of monooxygenases. Their members can be of critical function for the catabolism of xenobiotics. Mitochondria or cytochrome P450-dependent metabolism act as Reactive Oxygen Species (ROS) generation systems and participate in cell death processes. In the use of statins, hepatocytes produce a significant amount of ROS. They cause lipid peroxidation, thus leading to a decrease in the mitochondrial membrane potential and promoting cytotoxicity. All these 
effects are dose-and time-dependent although data are not shown at different doses of statins. The highest amount of ROS is produced by simvastatin (29). On the other hand, clinical trials have shown that the levels of ALT were higher in about $3 \%$ of subjects who received these drugs. However, such elevations are clinically insignificant in great majority of cases; indeed, the levels of ALT were greater than three times the ULN, but this was not seen in the majority of patients and when statins were in continuous use. This phenomenon, first the elevations in aminotransferases and then return to normal levels, is called adaptation, but it is not a well understood mechanism. This phenomenon is observed in a number of drugs, such as antidepressants (olanzapine) $(28,31)$. The cause of asymptomatic aminotransferase elevation caused by statins is unknown. One of speculations is that increased aminotransferases may actually arise from a pharmacodynamic effect of general lipid lowering drugs. This explanation may be plausible since the increased level of aminotransferases occur, with all lipid-lowering agents, not only statins, including ezetimibine that has no effect on hepatic cholesterol synthesis or bile acid excretion. Clinically significant liver injury by statins may be caused via idiosyncratic and immunoallergic mechanisms (27). In another study, it has been indicated that lactic acidosis plays an important role in the toxicity of statins. There is no evidence that lactic acidosis is an additive side effect or that it causes mitochondrial dysfunction (32).

\section{Case-control studies on statins}

There have been many published studies on the hepatotoxicity of statins. Statin group drugs are one of the best examples of difficulties encountered in attempting to strike the right benefit and risk balance with regard to DILI. Actually, the frequency of liver injury by statins is estimated to be 1 in 100000 patient-years. About $3 \%$ of patients who receive statin treatment experience an increase in aminotransaminases, but this increase typically normalises with continuous use. There are various studies on the safety of statins in patients with chronic liver disease. Statins can cause cholestatic and hepatocellular injury, rarely severe or fatal though. It is necessary to find a biomarker or any other tool for identifying the risk of DILI, also due to other commonly used drugs, not only statins (33).

There has been no evidence to support the cause and effect relationship for many other adverse effects. For example, in a well-designated long-term controlled followup study, patients $(n=170,000)$ showed that statins had no effect on liver disease, cancer, dementia, kidney disease, cerebral haemorrhages, memory impairment, or fatigue. Although liver function test (LFT) may be outside the normal range of $0.1 \%$ to $3 \%$ in subjects receiving higher doses of statins, when the statins are stopped, the tests return to this normal range. Permanent liver damage is extremely rare. Treatment with statins is associated with the diagnosis of new onset diabetes mellitus (DM). However, this risk is very low and statin therapy is preferred due to its benefits (34).

In another study, known as statin-induced liver injury (SILI) study, 108 cases and 324 controls were examined. The results showed that clinically significant elevations of liver enzymes were observed in four years. Most of the subjects in the case group were treated with high doses of different statins. There were no statistically significant differences in gender, age, LFT, type of liver injury, latency and severity, and Hepatitis B Virus (HBV) status (35).

\section{Meta analyses on statins}

Denus et al. (36) identified 13 meta-analyses of randomised, placebo-controlled studies. They investigated LFT abnormalities when four statins were used: lovastatin, simvastatin, pravastatin, fluvastatin. Only the 48-week trials were chosen because all these drugs are used in long-term treatments (37). Serum ALT and AST levels were used as the biomarker of liver injury in this meta-analysis and ALT was more deterministic than AST $(38,39)$. They concluded that placebo and statins gave similar results. However, LFT abnormalities were observed only for fluvastatin (fluvastatin $1.13 \%$ vs. placebo $0.29 \%, \mathrm{OR}=3.54,95 \% \mathrm{CI}=1.1-11.6$, $\mathrm{p}=0.04)$. They concluded that LFT abnormalities of fluvastatin were about three times higher than placebo due to $C Y P 2 C 9$ gene polymorphisms $(40,41)$. The variability of LFT abnormalities among the studies examined showed an inconsistency between fluvastatin and the results on other statins. They stated that low-moderate doses of pravastatin, lovastatin, and simvastatin did not cause a major risk with regard to LFT abnormalities (36). Genetic polymorphisms or individual susceptibility to drugs has become an important issue for drugs after the Human Genome Project (HGP), which was completed in 2000. After HGP, it was revealed that genetic makeup had a major impact on the pharmacological and toxicological effects of drugs. Especially, genetic polymorphisms in metabolising enzymes have a major impact on the statin-induced

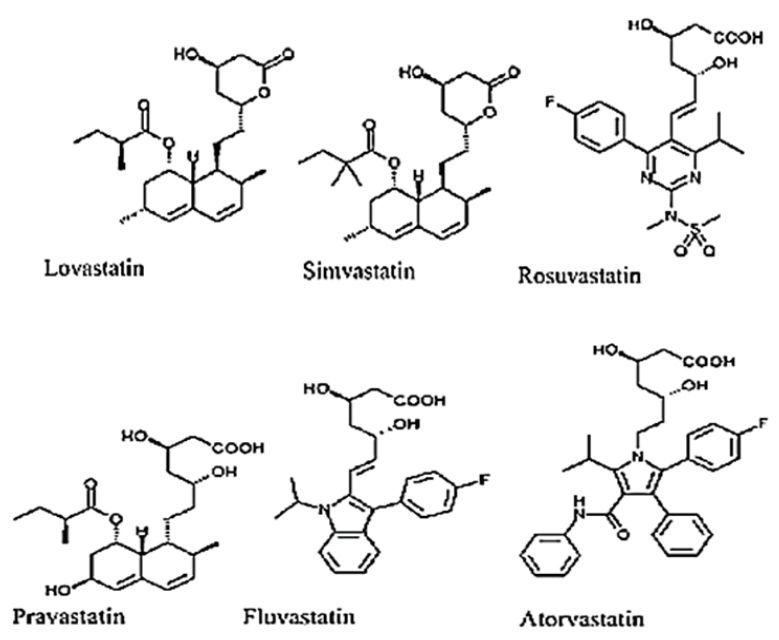

Figure 2 The six most commonly studied statins 
hepatotoxicity. Due to genetic polymorphisms, LFT abnormalities were frequently observed in statin treatments. Simvastatin is metabolised primarily by CYP3A4, when it is used concomitantly with amiodarone, which is an inhibitor of CYP3A4 enzyme; and interaction between these two drugs (simvastatin and amiodarone) increases hepatotoxicity (42). Another study, meta-analysis was carried out by Zhong et al. (43). They investigated the protective effects of statins relative to the risk of primary liver cancer. They searched all studies from PubMed and EMBASE databases. Risk ratios of six statins (lovastatin, simvastatin, pravastatin, fluvastatin, atorvastatin, rosuvastatin) were evaluated. They concluded that the use of statins decreased the risk of primary liver cancer. Notably, the protective effects of rosuvastatin were higher than those of the other statins (43).

\section{Epidemiological studies on statins}

A study involving a cohort of 185 patients who were treated with statins was conducted. Among these patients, only $2 \%$ had a previous chronic liver disease. At clinical presentation, $57.8 \%$ showed a hepatocellular pattern, $18.3 \%$ a cholestatic, and $23.2 \%$ a mixed one. Statins were involved in $4.3 \%$ of cases and were not frequently responsible for chronicity (44). DILI secondary to statins was investigated in Sweden by Bjornsson et al. (45). The Swedish Adverse Reactions Advisory Committee captured all spontaneously reported adverse reactions thought to be related to statins (1988-2010). Of 217 cases of all types of adverse events related to statins, 73 patients were identified to have a possible DILI. Seventy-one percent of liver injury cases were considered possibly related to statins, $19 \%$ were probable, and $10 \%$ highly probable. According to this study, statins can cause serious IDRs, but this remains an extremely rare phenomenon estimated to be observed in 1.6 cases per 100,000 person-years of use (46).

Among 1,188 cases of DILI enrolled between 2004 and 2012 in a prospective registry by the U.S. DILI Network, 22 were attributed to a statin. All patients were evaluated in a standard fashion and followed for at least six months after the onset. Nine patients developed cholestatic hepatitis and 12 patients hepatocellular injury, of which six had an autoimmune phenotype. Nine patients were hospitalised, four developed evidence of hepatic failure, and one died. All commonly used statins were implicated. Four patients developed chronic liver injury, of which three had an autoimmune phenotype of liver injury. Thus, DILI from statins is rare and characterised by variable patterns of injury, a range of latencies to onset, autoimmune features in some cases, and a persistent or chronic injury in $18 \%$ of patients, most of whom had the autoimmune phenotype (24).

In a large proportion of DILI reports, concomitant hepatotoxic and/or interacting drugs were recorded: $42 \%$ and $37 \%$ (rivaroxaban and dabigatran, respectively), especially statins, paracetamol and amiodarone (47). A prospective population-based study found a rough incidence of approximately 19 DILI cases per 100,000 and year. Although rare, statin-induced hepatotoxicity has been well documented (48). DILI from statins typically presents with an acute hepatocellular liver injury pattern, although mixed or cholestatic injury patterns have also been reported. Despite their widespread use, acute liver failure and death have rarely been reported in patients with statin hepatotoxicity. Multiple retrospective studies, as well as one large prospective randomised controlled trial demonstrate that statins can safely be given to hyperlipidaemic patients with compensated chronic liver disease (49).

Charles et al. (50) aimed to describe the rate, potential causes, symptoms, time to onset, and time to resolution of severe transaminitis associated with statin. ALT and AST had never been measured in $9 \%$ of eligible patients. In the remaining patients, $0.3 \%$, were identified with an ALT greater than 10 times the ULN. Of these, $17(0.1 \%)$ had severe transaminitis deemed directly attributable to statin use. In 16 cases, transaminitis resolved upon statin discontinuation. In this study, statin-related severe transaminitis occurred infrequently. These findings support less frequent liver enzyme monitoring for most patients on statins (50).

In the period 1994-2012, the Spanish Hepatotoxicity Registry recorded a total of 858 cases, 47 (5.5\%) of which were attributed to statins. Of these, $34 \%$ were due to atorvastatin, $27.7 \%$ to simvastatin, $25.5 \%$ to fluvastatin, $8.5 \%$ to lovastatin, and $4.3 \%$ to pravastatin. The hepatocellular pattern was predominant, especially in the simvastatin group (85\%), the cholestatic/mixed pattern was more frequent with fluvastatin $(66 \%)$ and had a similar distribution to that of atorvastatin. In conclusion, statins are not a common cause of hepatotoxicity. The liver injury pattern varies among different statins. The hepatitis phenotype with autoimmune features appears to be a characteristic signature of the statin-induced hepatotoxicity (51).

A nationwide population-based cohort study was conducted by the Taiwan National Health Insurance database. A total of 37,929 subjects with chronic liver disease who were on statin therapy were identified during 2005-2009. The outcome was defined as hospitalisation due to the liver injury. The overall incidence of hospitalisation due to severe hepatic injury was low among statin initiators with chronic liver disease. Only high-dose atorvastatin was associated with increased risk (52). Younoszai et al. (53) used the Third National Health and Nutrition Examination Survey (NHANES III)-mortality linked files to assess the association between statin use and liver-related mortality. Of all adult NHANES III participants enrolled in 1988-1994 $(n=20,050), 9,207$ individuals had sufficient demographic, clinical, and medical information making them eligible for this study. In this survey, the rate of liver-related mortality was significantly lower $(p=0.0035)$ among statin users 
compared to non-statin users. After a decade of follow up, there was no association between statin use and liver-related mortality (53). Despite their widespread use, statins are an uncommon cause of idiosyncratic DILI. Recent studies have shown that statins are actually safe and efficacious to be used in hyperlipidaemic patients with chronic liver disease (54). Statins rarely cause significant liver injury whereas antiretroviral therapy is associated with hepatotoxicity in $10 \%$ of treated patients (55).

\section{CONCLUSION}

Statins are extremely valuable in the treatment of human diseases and they have a widespread usage. There are many studies made on the hepatotoxicities of statins as well as other adverse effects such as cardiovascular disease, DM, and cancer risk. Epidemiological studies, since they are carried out on humans, are more valuable than individual studies and meta-analyses. In this review, conclusion is based on the most reliable and valuable study groups. The other major issue in the evaluation of the hepatotoxicity of statins is individual susceptibility to statins. Genetic polymorphism, notably of metabolising enzymes, has a major role in the hepatotoxicity of statins such as fluvastatin. Differences in the hepatotoxicity of statins are also observed among populations such as Spain and Taiwan. Drug-drug interactions also increase the hepatotoxicity of statins. The available data indicate that statins are not frequently responsible for liver injury, but there are several issues related to their usage in humans that require further research. More studies should be conducted to evaluate the pharmacokinetics of different statins at various doses, prolonged use of statins and long-term effects of statins on hepatic histology, and genetic polymorphisms. Finally, the current recommendations regarding liver biochemistry monitoring before and during statin therapy are not necessarily meaningful and they need to be re-examined by health sector employees.

\section{Conflict of interest}

There is no conflict of interest.

\section{REFERENCES}

1. Bjørneboe M, Iversen O, Olsen S. Infective hepatitis and toxic jaundice in a municipal hospital during a five-year period: incidence and prognosis. Acta Med Scand 1967;182:491-501. doi: 10.1111/j.0954-6820.1967.tb10873.x

2. Malchow-Møller A, Matzen P, Bjerregaard B, Hilden J, Holst-Christensen J, Staehr JT, Altman L, Thomsen C, Juhl E. Causes and characteristics of 500 consecutive causes of jaundice. Scand J Gastroenterol 1981;16:1-6. PMID: 7233075

3. Whitehead MW, Hainsworth I, Kingham JG. The causes of obvious jaundice in South West Wales: perceptions versus reality. Gut 2001;48:409-13. doi: 10.1136/gut.48.3.409
4. Björnsson E, Ismael S, Nejdet S, Kilander A. Severe jaundice in Sweden in the new millennium: causes, investigations, treatment and prognosis. Scand J Gastroenterol 2003;38:8694. doi: 10.1080/00365520310000492

5. Ostapowicz G, Fontana RJ, Schiodt FV, Larson A, Davern TJ, Han SHB, McCashland TM, Shakil AO, Hay JE, Hynan L, Crippin JS, Blei AT, Samuel G, Reisch J, Lee WM; U.S. Acute Liver Failure Study Group. Results of a prospective study of acute liver failure at 17 tertiary care centers in the United States. Ann Intern Med 2002;137:947-54. doi: 10.7326/0003-4819-137-12-200212170-00007

6. Williams R. Classification, etiology, and considerations of outcome in acute liver failure. Semin Liver Dis 1996;16:3438. doi: 10.1055/s-2007-1007247

7. Wei G, Bergqvist A, Broome U, Björnsson E. Acute liver failure in Sweden: etiology and prognosis. Scand J Gastroenterol 2004;39(Suppl 240):48A.

8. O'Grady JG, Alexander GJM, Hayllar KM, Williams R. Early indicators of prognosis in fulminant hepatic failure. Gastroenterology 1989;97:439-45. doi: 10.1016/00165085(89)90081-4

9. Hoofnagle JH, Carithers RL Jr, Shapiro C, Nascher H. Fulminant hepatic failure: summary of a workshop. Hepatology 1995;21:240-52. doi: 10.1016/02709139(95)90434-4

10. Bakke OM, Manocchia M, de Abajo F, Kaitin KI, Lasagna L. Drug safety discontinuations in the United Kingdom, the United States, and Spain from 1974 through 1993: a regulatory perspective. Clin Pharm Therap 1995;58:108-17. doi: 10.1016/0009-9236(95)90078-0

11. Zimmerman HJ. Drug-induced liver disease. Clin Liver Dis 2000;4:73-96. PMID: 11232192

12. Black M, Mitchell JR, Zimmerman HJ, Ishak KG, Epler GR. Isoniazid-associated hepatitis in 114 patients. Gastroenterology 1975;69:289-302. PMID: 1150039

13. Senior JR. Regulatory perspectives. In: Kaplowitz N, DeLeve D, editors. Drug-induced liver disease. New York: Marcel Dekker; 2003. p. 739-54.

14. Zimmerman HJ. Drug-induced liver disease. In: Sciff ER, Sorrell MF, Maddrey WC, editors. Sciff's diseases of the liver. $8^{\text {th }}$ edition. Philadelphia: Lippincott-Raven Publishers; 1999. p. 973-1064.

15. Pillans PI. Drug associated hepatic reactions in New Zealand: 21-years' experience. N Z Med J 1996;109:315-9. PMID: 8816722

16. Friis H, Andreasen PB. Drug-induced hepatic injury: an analysis of 1100 cases reported to the Danish Committee on Adverse Drug Reactions between 1978 and 1987. J Intern Med 1992;232:133-8. doi: 10.1111/j.1365-2796.1992. tb00562.x

17. Golomb BA, Evans MA. Statin adverse effects: a review of the literature and evidence for a mitochondrial mechanism. Am J Cardiovasc Drugs 2008;8:373-418. doi: 10.2165/0129784-200808060-0000

18. Björnsson E, Olsson R. Outcome and prognostic markers in severe drug-induced liver disease. Hepatology 2005;42:4819. doi: 10.1002/hep.20800

19. Kshirsagar A, Vetal Y, Ashok P, Bhosle P, Ingawale D. Drug induced hepatotoxicity: a comprehensive review. Internet J Pharmacol 2008 [displayed 18 October 2017]. Available at http://ispub.com/IJPHARM/7/1/3723 
20. Cohen DE, Anania FA, Chalasani N. An assessment of statin safety by hepatologists. Am J Cardiol 2006;97(Suppl 1):77C-81C. doi: 10.1016/j.amjcard.2005.12.014

21. Bhardwaj SS, Chalasani N. Lipid lowering agents that cause drug-induced hepatotoxicity. Clin Liver Dis 2007;11:597613. doi: 10.1016/j.cld.2007.06.010

22. Kubota T, Fujisaki K, Itoh Y, Yano T, Sendo T, Oishi R. Apoptotic injury in cultured human hepatocytes induced by HMG-CoA reductase inhibitors. Biochem Pharmacol 2004;67:2175-86. doi: 10.1016/j.bcp.2004.02.037

23. Wolters LMM, Van Buuren HR. Rosuvastatin-associated hepatitis with autoimmune features. Eur J Gastroenterol Hepatol 2005;17:589-90. PMID: 15827453

24. Russo MW, Hoofnagle JH, Gu J, Fontana RJ, Barnhart H, Kleiner DE, Chalasani N, Bonkovsky HL. Spectrum of statin hepatotoxicity: experience of the drug-induced liver injury network. Hepat 2014;60:679-86. doi: 10.1002/hep.27157

25. Kubatka P, Kruzliak P, Rotrekl V, Jelinkova S, Mladosievicova B. Statins in oncological research: from experimental studies to clinical practice. Crit Rev Oncol Hematol 2014;92:296311. doi: 10.1016/j.critrevonc.2014.08.002

26. Cueto R, Valdivielso P, Lucena MI, García-Arias C, Andrade RJ, Gonzólez-Santos P. Statins: hepatic disease and hepatotoxicity risk. Open Gastroenterol J 2008;2:18-23. doi $10.2174 / 1874259900802010018$

27. Chalasani N. Statins and hepatotoxicity: focus on patients with fatty liver. Hepat 2005;41:690-5. doi: 10.1002 hep.20671

28. Thapar M, Russo MW, Bonkovsky HL. Statins and liver injury. Gastroenterol Hepatol 2013;9:605-6. PMCID PMC3983981

29. Abdoli N, Azarmi Y, Eghbal MA. Protective effects of $\mathrm{N}$-acetylcysteine against the statins cytotoxicity in freshly isolated rat hepatocytes. Adv Pharm Bull 2014;4:249-54. doi: 10.5681/apb.2014.036

30. Tolosa L, Carmona A, Castell JV, Gómez-Lechón MJ, Donato MT. High-content screening of drug-induced mitocondrial impairment in hepatic cells: effects of statins. Arch Toxicol 2015;89:1847-60. doi: 10.1007/s00204-014-1334-3

31. Ciba M, Ak M, Karahalil B. Alpha-glutathione-s-transferase can be a biomarker for both drug-related toxicity as well as individual susceptibility. Minerva Psichiatr 2016;57:62-71.

32. Abdoli N, Heidari R, Azarmi Y, Eghbal MA. Mechanism of the statins cytotoicity in freshly isolated rat hepatocytes. J Biochem Molecular Toxicol 2013;27:287-94. doi: 10.1002/ jbt21485

33. Haque T, Sasatomi E, Hayashi PH. Drug-induced liver injury: Pattern recognition and future directions. Gut Liver 2016;10:27-36. doi: 10.5009/gnl15114

34. Fitchett DH, Hegele RA, Verma S. Cardiology patient page. Statin intolerance. Circulation 2015;131:e389-91. doi: 10.1161/CIRCULATIONAHA.114.013189

35. Wang LY, Huang Y, Perng C, Huang B, Lin H. Statin-induced liver injury in an area endemic for hepatitis $\mathrm{B}$ virus infection: risk factors and outcome analysis. Br J Clin Pharmacol 2016;82:823-30. doi: 10.1111/bcp.13009

36. de Denus S, Spinler SA, Miller K, Peterson AM. Statins and liver toxicity: a meta-analysis. Pharmacotherapy 2004;24:58491. doi: 10.1592/phco.24.6.584.34738

37. Bradford RH, Shear CL, Achanassios N, Chremos AN, Dujovne C, Downton M, Franklin FA, Gould AL, Hesney M, Higgins J, Hurley DP, Langendorfer A, Nash DT, Pool
JL, Schnaper H. Expanded clinical evaluation of lovastatin (EXCEL) study results. I. Efficacy in modifying plasma lipoproteins and adverse event profile in 8245 patients with moderate hypercholesterolemia. Arch Intern Med 1991;151:43-9. doi: 10.1001/archinte.1991.00400010067008

38. Roberts WC. Getting more people on statins. Am J Cardiol 2002;90:683-5. doi: 10.1016/S0002-9149(02)02590-0

39. Tolman KG. The liver and lovastatin. Am J Cardiol 2002;89:1374-80. doi: 10.1016/S0002-9149(02)02355-X

40. Kirchheiner J, Kudlicz D, Meisel C, Bauer S, Meineke I, Roots I, Brockmöller J. Influence of CYP2C9 polymorphisms on the pharmacokinetics and cholesterollowering activity of $(-)-3 \mathrm{~S}, 5 \mathrm{R}$-fluvastatin and (+)-3R,5S-fluvastatin in healthy volunteers. Clin Pharmacol Ther 2003;74:186-94. doi: 10.1016/S0009-9236(03)00121-8

41. Flockhart DA, Rae JM. Cytochrome P450 3A pharmacogenetics: the road that needs traveled. Pharmacogenom J 2003;3:3-5. doi: 10.1038/sj.tpj.6500144

42. Chalasani N, Björnsson E. Risk factors for idiosyncratic drug-induced liver injury. Gastroenterology 2010;138:224659. doi: 10.1053/j.gastro.2010.04.001

43. Zhong G, Liu Y, Ye Y, Hao F, Wang K, Gong J. Meta-analysis of studies using statins as a reducer for primary liver cancer risk. Sci Rep 2016;26256-65. doi: 10.1038/srep26256

44. Licata A, Minissale MG, Calvaruso V, Craxì A. A focus on epidemiology of drug-induced liver injury: analysis of a prospective cohort. Eur Rev Med Pharmacol Sci 2017;21(Suppl 1):112-21. PMID: 28379588

45. Björnsson E, Jacobsen EI, Kalaitzakis E. Hepatotoxicity associated with statins: reports of idiosyncratic liver injury post-marketing. J Hepatol 2012;56:374-80. doi: 10.1016/j. jhep.2011.07.023

46. Leise MD, Poterucha JJ, Talwalkar JA. Drug-induced liver injury. Mayo Clin Proc 2014;89:95-106. doi: 10.1016/j. mayocp.2013.09.016

47. Raschi E, Poluzzi E, Koci A, Salvo F, Pariente A, Biselli M, Moretti U, Moore N, De Ponti F. Liver injury with novel oral anticoagulants: assessing post-marketing reports in the US Food and Drug Administration adverse event reporting system. Br J Clin Pharmacol 2015;80:285-93. doi: 10.1111/ bcp. 12611

48. Björnsson ES. Drug-induced liver injury: an overview over the most critical compounds. Arch Toxicol 2015;89:327-34. doi: 10.1007/s00204-015-1456-2

49. Russo MW, Scobey M, Bonkovsky HL. Drug-induced liver injury associated with statins. Semin Liver Dis 2009;29:41222. doi: $10.1055 / \mathrm{s}-0029-1240010$

50. Charles EC, Olson KL, Sandhoff BG, McClure DL, Merenich JA. Evaluation of cases of severe statin-related transaminitis within a large health maintenance organization. Am J Med 2005;118:618-24. doi: 10.1016/j.amjmed.2005.02.008

51. Perdices EV, Medina-Cáliz I, Hernando S, Ortega A, MartínOcaña F, Navarro JM, Peláez G, Castiella A, Hallal H, Romero-Gómez M, González-Jiménez A, Robles-Díaz M, Lucena MI, Andrade RJ. Hepatotoxicity associated with statin use: analysis of the cases included in the Spanish Hepatotoxicity Registry. Rev Esp Enferm Dig 2014;106:24654. PMID: 25075655

52. Chang CH, Chang YC, Lee YC, Liu YC, Chuang LM, Lin JW. Severe hepatic injury associated with different statins in patients with chronic liver disease: a nationwide population- 
based cohort study. J Gastroenterol Hepatol 2015;30:155-62. doi: 10.1111/jgh.12657

53. Younoszai Z, Li Z, Stepanova M, Erario M, Cable R, Younossi ZM. Statin use is not associated with liver related mortality. Ann Hepatol 2014;13:84-90. doi: 10.1007/s11274015-1903-5
54. Rangnekar AS, Fontana RJ. An update on drug induced liver injury. Minerva Gastroenterol Dietol 2011;57:213-29. PMID: 21587150

55. Hussaini SH, Farrington EA. Idiosyncratic drug-induced liver injury: an overview. Expert Opin Drug Saf 2007;6:673-84. doi: $10.1517 / 14740338.6 .6 .673$

\section{Hepatotoksičnost povezana sa statinima}

Terapija statinima opće je prihvaćena diljem svijeta i njihove se terapijske doze općenito smatraju sigurnima. Ipak, klinička ispitivanja nisu dostatna kako bi se procijenile rijetke nuspojave primjene statina, poput idiosinkratske lijekom izazvane ozljede jetara (drug induced liver injury - DILI). Zbog nekih stanja poput istodobne uporabe određenih lijekova (interakcija dvaju lijekova koji imaju isti metabolizirajući enzim) i genskih polimorfizama, javlja se određena zabrinutost u vezi s njihovom sigurnom primjenom. U brojnim se studijama kao nuspojave primjene statina navode hepatotoksičnost $\mathrm{i}$ rabdomioliza. Većina istraživanja usredotočena je na nuspojave i mehanizme lijekom izazvane toksičnosti. U ovom se preglednom radu nastoje sažeti gotovo sve postojeće studije o hepatotoksičnosti statina, ali ne i o rabdomiolizi. Cilj je ponuditi pregled istraživanja hepatotoksičnosti koja je povezana s uporabom statina te razraditi objavljene rezultate tih istraživanja. Istraživači su mišljenja da je istraživanje ovoga problema nepotpuno ali prijeko potrebno. 